\title{
Ceftaroline resistance in Staphylococcus pseudintermedius gene mecA carriers ${ }^{1}$
}

\author{
Carolina B. Scherer ${ }^{2}$, Larissa S. Botoni ${ }^{2}$, Antônio U. Carvalho², Kelly M. Keller ${ }^{3}$ \\ and Adriane P. Costa-Val ${ }^{2 *}$
}

\begin{abstract}
Scherer C.B., Botoni L.S., Carvalho A.U., Keller K.M. \& Costa-Val A.P. 2018. Ceftaroline resistance in Staphylococcus pseudintermedius gene mecA carriers. Pesquisa Veterinária Brasileira 38(12):2233-2236. Departamento de Clínica e Cirurgia, Escola de Medicina Veterinária, Universidade Federal de Minas Gerais, Av. Antônio Carlos 6627, Cx. Postal 567, Belo Horizonte, MG 31270-901, Brazil. E-mail: adriane@ufmg.br

Infections caused by methicillin-resistant Staphylococcus aureus (MRSA) being a constant concern, ceftaroline fosamil has been recently approved as a new cephalosporin, active against MRSA, for use in humans; only rare cases of resistance have been reported till date. There is no report of resistance to ceftaroline in Staphylococcus pseudintermedius, which is the main bacterium causing dermatitis and otitis in dogs. To evaluate staphylococcal resistance to ceftaroline, 35 isolates of methicillin-resistant S. pseudintermedius (MRSP), carrying the mecA gene, from 26 dogs with folliculitis and nine dogs with external otitis, underwent disk diffusion test with cefoxitin, oxacillin, and ceftaroline. Tests with cefoxitin and oxacillin showed $>90 \%$ sensitivity in methicillin resistance detection. In the disk diffusion test, $97.14 \%$ (34/35) were resistant to cefoxitin, $94.29 \%$ (33/35) to oxacillin, and $31.43 \%$ $(11 / 35)$ to ceftaroline. Of the ceftaroline-resistant strains, $27.27 \%(3 / 11)$ were obtained from the ears of dogs while the rest (8/11) were from the skin. The current report is the first description of MRSP resistance to ceftaroline.
\end{abstract}

INDEX TERMS: Ceftaroline, resistance, Staphylococcus pseudintermedius, mecA gene, MRSP, cefoxitin, oxacillin, dogs, bacterioses.

RESUMO.- [Resistência à ceftarolina em Staphylococcus pseudintermedius portadores do gene mecA.] Infecções causadas por Staphylococcus aureus resistente à meticilina (MRSA) são uma preocupação médica constante. A ceftarolina fosamila é uma nova cefalosporina ativa contra Staphylococcus aureus resistente à meticilina recentemente aprovada para uso em humanos e raros casos de resistência relatados até agora. Não há relatos de resistência à ceftarolina em Staphylococcus pseudintermedius, principal bactéria causadora de dermatite e otite em cães. Com o objetivo de avaliar a resistência estafilocócica à ceftarolina, 35 amostras de S. pseudintermedius resistentes à meticilina (MRSP),

\footnotetext{
${ }^{1}$ Received on August 29, 2018.

Accepted for publication on September 12, 2018.

${ }^{2}$ Departamento de Clínica e Cirurgia, Escola de Medicina Veterinária, Universidade Federal de Minas Gerais (UFMG), Campus da Pampulha, Av. Antônio Carlos 6627, Belo Horizonte, MG 31270-901, Brazil. *Corresponding author: adriane@ufmg.br

${ }^{3}$ Departamento de Medicina Veterinária Preventiva, Escola de Medicina Veterinária, Universidade Federal de Minas Gerais (UFMG), Campus da Pampulha, Av. Antônio Carlos 6627, Belo Horizonte, MG 31270-901.
}

portadoras do gene $m e c A$, provenientes de 26 cães com foliculite e 9 com otite externa foram submetidos ao teste de disco-difusão com cefoxitina, oxacilina e ceftarolina. Os testes realizados com cefoxitina e oxacilina mostraram mais de $90 \%$ de sensibilidade na detecção da resistência à meticilina em ambas. No teste da disco-difusão, 97,14\% (1/35) foram resistentes à cefoxitina, $94,29 \%(3 / 35)$ à oxacilina e $31,43 \%$ $(11 / 35)$ à ceftarolina. Das cepas resistentes às ceftarolina, 27,27 (3/11) foram provenientes de ouvido de cães e as demais (8/11), provenientes da pele, sendo essa primeira descrição de resistência de MRSP à ceftarolina na literatura atual.

TERMOS DE INDEXAÇÃO: Resistência, ceftarolina, Staphylococcus pseudintermedius, gene mecA, susceptibilidade, disco-difusão, MRSP, cefoxitina, oxacilina, caninos, bacterioses.

\section{INTRODUCTION}

Treatment of skin and ear infections caused by methicillin-resistant Staphylococcus pseudintermedius (MRSP) is a constant concern in the veterinary community. MRSP are resistant to 
all $\beta$-lactams, including the cephalosporins (Cain 2013), which form the most prescribed class of antimicrobials worldwide, due to their broad spectrum of action and low frequency of adverse effects (Laudano 2011).

Ceftaroline fosamil, a new parenteral antibiotic used for the treatment of severe skin and soft-tissue infections, was approved for use in humans in the United States (2010), Europe (2012), and Brazil (2014) (Laudano 2011, Alm et al. 2014, Anvisa 2014). Ceftaroline fosamil exhibits a broad spectrum of activity, acting on both gram-negative and -positive bacteria, and hence considered by the Clinical and Laboratory Standards Institute (CLSI) guidelines as a new subclass of antimicrobials, cephalosporins, exhibiting activity against methicillin-resistant Staphylococcus aureus (MRSA) (Laudano 2011).

Staphylococci, resistant to $\beta$-lactamase-stable anti-staphylococcal penicillin, have been termed as "methicillin-resistant", even though methicillin is no longer the drug of choice for testing resistance by the disk diffusion test. According to Mimica et al. (2007), oxacillin disk-diffusion test has been the most widely used test for decades; however, oxacillin was subsequently replaced by cefoxitin, which induces the expression of the resistance-associated gene much more strongly in S. aureus. However, oxacillin continues to be used for the detection of methicillin-resistance in S. pseudintermedius (CLSI 2013, 2017).

Resistance to methicillin is associated with the presence of $m e c A$ gene, which is responsible for altering the sequence of penicillin-binding protein (PBP2a) present in the bacterial cell wall (Cain 2013). Historically, staphylococci had demonstrated resistance to cephalosporins and other $\beta$-lactam antibiotics due to the low affinity of these drugs to the modified PBP2a (Kosowska-Shick et al. 2010).

Evidence shows that the mecA gene originates from Staphylococcus sciuri, with a possible horizontal transfer to $S$. aureus and other staphylococcal species, including those affecting the skin and ears of dogs, such as $S$. pseudintermedius and Staphylococcus schleiferi (Wu et al. 1996, Bemis et al. 2006). In addition to the presence of these microorganisms in pigs and horses, there are reports of MRSA transmission between humans and dogs, (Weese \& Van Duijkeren 2010), and dogs transmitting MRSP to humans (Lozano et al. 2017).

According to the guidelines of CLSI (2017), any strain containing the mecA gene must be reported as resistant to methicillin, given the rarity of other mechanisms of methicillin resistance (Petersen et al. 2013). Additionally, according to the guidelines of CLSI (2013), any oxacillin-resistant S. pseudintermedius must be considered resistant to methicillin and all $\beta$-lactams.

Unlike other $\beta$-lactams, which have low affinity for PBP2a, competitive assays demonstrated high affinity of ceftaroline to the allosteric domain of MRSA PBP2a, along with its ability to induce a conformational change potentially leading to exposure of an active antibiotic-binding site, thereby allowing a second ceftaroline molecule to bind to that site and block the activity of the protein (Kosowska-Shick et al. 2010). However, despite its veterinary importance and zoonotic potential, there is no report on the dual resistance of MRSP, carrying the mecA gene, to ceftaroline and methicillin in samples from dogs.

The current study aimed to: 1) compare the ceftaroline resistance in MRSP strains carrying the mecA gene, isolated from dogs with folliculitis and/or otitis externa, 2) to compare the sensitivity of oxacillin and cefoxitin disks in the disk-diffusion test for the diagnosis of MRSP strains, and 3) to evaluate the staphylococcal resistance to ceftaroline in the MRSP samples collected from dogs with folliculitis and/or otitis externa.

\section{MATERIALS AND METHODS}

Strain selection. Thirty-five Staphylococcus pseudintermedius strains were included in the study; nine were isolated from ear secretion and 26 from the skin of dogs with positive cytological evaluation for coccoid bacteria and previously treated for MRSP infection at the Department of Dermatology, Veterinary Hospital of the Federal University of Minas Gerais, from April to October 2013. Biochemical tests were performed for phenotypic identification of the members of Staphylococcal intermedius group (SIG), as previously described (Quinn 2011 and polymerase chain reaction (PCR) was conducted for the genotypic identification of $S$. pseudintermedius according to Sasaki et al. (2010) The protocols were approved by the Ethical Committee for Animal Usage (CEUA, protocol 246/2013). Written informed consent to allow sample collection from the dogs was obtained from the owners.

DNA extraction. Strains were cultured in Mueller-Hinton agar, and one colony from each culture was transferred to a micro tube containing $20 \mu \mathrm{L}$ of Milli-Q water. The bacterial suspensions were heated in a water bath at $100^{\circ} \mathrm{C}$ for $15 \mathrm{~min}$ and centrifuged at $60 \mathrm{rpm}$, with a power of $10 \mathrm{~mA}$ for $5 \mathrm{~min}$ (HSIANGTAI Centrifuge, MCD-2000, New Taipei City, Taiwan). The supernatant was collected and used as the DNA sample.

Detection of $\boldsymbol{m e c A}$ gene. All strains were analyzed by PCR for the detection of $m e c A$ gene using the primers F: $5^{\prime}$-ACTGCTATCCACCCTCAAC- ${ }^{\prime}$ and R: 5'-CTGGTGAAGTTGTAATCTGG-3', as described by Merothra et al. (2000).

Strains of S. pseudintermedius (MRSP 3279) and Staphylococcus aureus (USA 100) were used as positive controls, whereas amplification sample without template DNA was used as a negative control.

Susceptibility tests. The disk-diffusion method, recommended by the CLSI $(2013,2017)$, was used for phenotypic resistance testing. Each MRSP strain, confirmed by mecA gene detection, was suspended in $3 \mathrm{~mL}$ of Mueller-Hinton broth and incubated at $35^{\circ} \mathrm{C}$ until a turbidity equivalent to 0.5 of the McFarland scale was reached (Bannoehr \& Guardabassi 2012). Aliquots of the suspension were streaked on Mueller-Hinton agar plates (4-mm agar depth). Disks impregnated with $30 \mu \mathrm{g}$ ceftaroline (HardyDisk, Santa Maria/CA), $1 \mu \mathrm{g}$ oxacillin, and $30 \mu \mathrm{g}$ cefoxitin (Laboratório DME, Araçatuba, São Paulo, Brazil) were used. After 24-h incubation, the inhibition halos formed around the disks were measured and compared to the zone diameters published by CLSI (2017) for cefoxitin and ceftaroline to S. aureus and by CLSI (2013) for oxacillin to S. pseudintermedius.

Statistical analysis. Pearson's chi-squared test for equality of proportions was used for statistical analysis. The level of significance used in the statistical-test decisions was 5\%. Statistical analyses were performed using the program SAS (SAS Institute Inc., Cary/NC). Cramér's V coefficient was used to evaluate the intensity of association between the studied variables.

\section{RESULTS}

All 35 samples were confirmed as MRSP by the PCR assays; however, the susceptibility results using oxacillin and cefoxitin disks varied. Of the analyzed strains, 5.71\% (2/35) were 
susceptible to oxacillin while $2.96 \%(1 / 35)$ were susceptible to cefoxitin (Table 1).

Among the tested MRSP strains, 31.43\% (11/35) were resistant to ceftaroline. From the resistant strains, $27.27 \%$ (3/11) were from otitis while the rest (8/11) were from the skin. Additionally, Cramér's V value was 0.5 , demonstrating a strong association among the resistance to the three antibiotics.

\section{DISCUSSION}

In this study, the disk-diffusion method with cefoxitin, a test recommended by the CLSI (2017) for S. aureus, was compared to that with oxacillin, a method still widely used for Staphylococcus aureus and considered standard for S. pseudintermedius by the veterinary CLSI (2013). Cefoxitin was more sensitive to the test, with $34 / 35(97.14 \%)$ resistant samples, compared to oxacillin, with 33/35 (94.29\%) resistant samples. All 35 strains were methicillin/oxacillin-resistant, according to the gold standard test for detection that involves PCR to investigate the presence of mecA gene (Velasco et al. 2005, Mimica et al. 2007). Studies comparing the cefoxitin and oxacillin disks had previously shown high specificity of both, with a greater sensitivity for cefoxitin demonstrated by Velasco et al. (2005), and an opposite result demonstrated by Mimica et al. (2007). Regarding oxacillin, the halo size, adopted to predict susceptibility, was $\leq 17 \mathrm{~mm}$, as recommended by the CLSI (2017), resulting in the identification of $2 / 35$ (5.71\%) susceptible samples. Detection of susceptible strains might also suggest that, even in the presence of mecA gene, resistance might not be expressed. In case of serious infection and susceptibility results in disk-diffusion test, if PCR would not be feasible, clinical laboratories can routinely adopt the determination of MIC values, a test more accurate than disk-diffusion.

Previous studies had compared oxacillin resistance, according to the disk-diffusion method, and the presence of $m e c A$ in staphylococcal strains collected from dogs. While Kania et al. (2004) found oxacillin-susceptible samples harboring the gene; Bemis et al. $(2006,2009)$ observed that the mecA gene was present in all oxacillin-resistant staphylococcal samples. In the studies reporting $100 \%$ resistance, diameter of the halo, considered to represent resistance, was $\leq 17 \mathrm{~mm}$, which was adopted by the CLSI from 2004 to 2008 for S. aureus and in 2013 to standardize the disc-diffusion test for microorganisms present in animals. In studies identifying susceptible strains, the diameter used to determine oxacillin resistance was $\leq 10 \mathrm{~mm}$. In the present study, since the samples underwent disk-diffusion test after identification of the mecA gene, all samples were known to carry the mecA gene, in contrast to the studies of Bemis et al. $(2006,2009)$, who selected the samples based on halo sizes $\leq 17 \mathrm{~mm}$ to investigate the presence of the gene. Since the size of the halo decreased to

Table 1. Resistance values of MRSP to cefoxitin, oxacillin, and ceftaroline

\begin{tabular}{cccccccc}
\hline & \multicolumn{2}{c}{ Susceptible } & & \multicolumn{2}{c}{ Resistant } & \multirow{2}{*}{$p$} \\
\cline { 2 - 3 } & $n$ & $\%$ & & $n$ & $\%$ & \\
\hline Cefoxitin & 1 & 2.86 & & 34 & 97.14 & $<0.0001$ \\
Oxacillin & 2 & 5.71 & & 33 & 94.29 & $<0.0001$ \\
Ceftaroline & 24 & 68.57 & & 11 & 31.43 & $<0.0001$
\end{tabular}

$\leq 10 \mathrm{~mm}$, in order to increase the sensitivity and efficacy of the test, the gene-carrying strains were probably discarded in the studies owing to the larger diameter.

In dogs S. pseudintermedius is the main causative agent of bacterial folliculitis and otitis externa. The increased incidence of these methicillin-resistant microorganisms over the last decade has reduced the efficacy of treatments using $\beta$-lactams, besides the fact that these bacteria are often resistant to multiple classes of antimicrobials (Bemis et al. 2009).

The use of ceftaroline in animals has not been described yet; therefore, there is no report of resistance in susceptibility tests using this antimicrobial in staphylococci present on the skin and mucous membranes of dogs (Sader et al. 2016). Till date, there had been no report of resistance for MRSP (Bannoehr \& Guardabassi 2012) and MRSA (considering their similarities), it is necessary to find alternatives such as ceftaroline. Considering that there is no breakpoint determined for ceftaroline in S. pseudintermedius, and the one for S. aureus was adopted in this study, the current results showed that $31.43 \%$ (range: $0-3 \%)(11 / 35)$ of the staphylococci had resistance to ceftaroline, much higher than MRSA resistance in humans (Sader et al. 2015). The breakpoint value (if determined) may be higher for S. pseudintermedius, which will result in less resistant strains. The ability of ceftaroline to bind to modified PBP2a is the biggest difference with the other $\beta$-lactams (Kosowska-Shick et al. 2010), the mutation and adaptation potentials of $S$. pseudintermedius (present in dogs) and S. aureus are similar, since closely related strains of these bacteria have been identified (Bannoehr \& Guardabassi 2012). S. aureus strains, resistant to ceftaroline from Thailand, have a very similar genetic background, suggesting a clonal propagation (Alm et al. 2014). The same phenomenon might have occurred in the present study, given that all the strains were collected from dogs of the same community, which might explain the high resistance rates of $S$. pseudintermedius.

Ceftaroline fosamil, approved by the FDA in 2012 despite the absence of resistance reports of $>4 \%$ in MRSA, showed high resistance in MRSP, when the disc diffusion test was performed with the parameters for $S$. aureus. Since human medications are usually used in pets, and MRSP causes chronic and recurrent dermatopathies in dogs, the necessity for standardization of resistance tests against ceftaroline in S. pseudintermedius, still remains high.

\section{CONCLUSIONS}

There was no significant difference between the resistance values obtained for samples collected from the ear and those collected from the skin of dogs. Staphylococcus pseudintermedius, carrying the $m e c A$ gene, showed more than $90 \%$ resistance to cefoxitin and oxacillin.

The antimicrobials used in the disk-diffusion method to detect methicillin resistance showed sensitivity, with cefoxitin being more sensitive. Resistance rate of S. pseudintermedius to ceftaroline $(33.31 \%)$ was considered high, when the breakpoint for $S$. aureus was used, given that there was no previous report of resistance in this microorganism.

\section{REFERENCES}

Alm R.A., McLaughlin R.E., Kos V.N., Sader H.S., Iaconis J.P. \& Lahiri S.D. 2014. Analysis of Staphylococcus aureus clinical isolates with reduced susceptibility to ceftaroline: an epidemiological and structural perspective. 
J. Antimicrob. Chemother. 69(8):2065-2075. <http://dx.doi.org/10.1093/ jac/dku114><PMid:24777906>

Anvisa 2014. Banco de Dados/Medicamentos. Brasília. Available at <http:// www7.anvisa.gov.br/datavisa/Consulta_Produto/rconsulta_produto_ detalhe.asp> Accessed on Aug. 31, 2015.

Bannoehr J. \& Guardabassi L. 2012. Staphylococcus pseudintermedius in the dog: taxonomy, diagnostics, ecology, epidemiology and pathogenicity. Vet. Dermatol. 23(4):253-266. <http://dx.doi.org/10.1111/j.1365-3164.2012.01046.x> $<$ PMid:22515504>

Bemis D.A., Jones R.D., Frank L.A. \& Kania S.A. 2009. Evaluation of susceptibility test breakpoints used to predict mecA-mediated resistance in Staphylococcus pseudintermedius isolated from dogs. J. Vet. Diagn. Invest. 21(1):53-58. <http://dx.doi.org/10.1177/104063870902100108><PMid:19139501>

Bemis D.A., Jones R.D., Hiatt L.E., Ofori E.D., Rohrbach B.W., Frank L.A. \& Kania S.A. 2006. Comparison of tests to detect oxacillin resistance in Staphylococcus intermedius, Staphylococcus schleiferi, and Staphylococcus aureus isolates from canine hosts. J. Clin. Microbiol. 44(9):3374-3376. <http://dx.doi. org/10.1128/JCM.01336-06><PMid:16954277>

Cain C.L. 2013. Antimicrobial resistance in staphylococci in small animals. Vet. Clin. N. Am., Small Anim. Pract. 43(1):19-40. <http://dx.doi.org/10.1016/j. cvsm.2012.09.003><PMid:23182322>

CLSI 2013. Performance Standards for Antimicrobial Disk and Dilution Susceptibility Tests for Bacteria Isolated from Animals: second informational supplement. Wayne, Pennsylvania, USA.

CLSI 2017. Performance Standards for Antimicrobial Susceptibility Testing: twenty-seventh informational supplement. Wayne, Pennsylvania, USA.

Kania S.A., Williamson N.L., Frank L.A., Wilkes R.P., Jones R.D. \& Bemis D.A. 2004. Methicillin resistance of staphylococci isolated from the skin of dogs with pyoderma. Am. J. Vet. Res. 65(9):1265-1268. <http://dx.doi. org/10.2460/ajvr.2004.65.1265> <PMid:15478775>

Kosowska-Shick K., Mcghee P. \& Appelbaum P.C. 2010. Affinity of ceftaroline and other beta-lactams for penicillin-binding proteins from Staphylococcus aureus and Streptococcus pneumoniae. Antimicrob. Agents Chemother. 54(5):16701677. <http://dx.doi.org/10.1128/AAC.00019-10> <PMid:20194704>

Laudano J.B. 2011. Ceftaroline fosamil: a new broad-spectrum cephalosporin. J. Antimicrob. Chemother. 66(Suppl.3):11-18. <http://dx.doi.org/10.1093/ jac/dkr095><PMid:21482565>

Lozano C., Rezusta A., Ferrer I., Pérez-Laguna V., Zarazaga M., Ruiz-Ripa L., Revillo M.J. \& Torres C. 2017. Staphylococcus pseudintermedius human infection cases in Spain: dog-to-human transmission. Vector-Borne Zoonotic Dis. 17(4):268-270.<http://dx.doi.org/10.1089/vbz.2016.2048> <PMid:28075235>

Mehrotra M., Wang G. \& Johnson W.M. 2000. Multiplex PCR for detection of genes for Staphylococcus aureus enterotoxins, exfoliative toxins, toxic shock syndrome toxin 1, and methicillin resistance. J. Clin. Microbiol. 38(3):1032-1035. PMid:10698991.

Mimica M.J., Berezin E.N., Carvalho R.L.B., Mimica I.M., Mimica L.M.J., Sáfadi M.A.P., Schneider E. \& Caiaffa-Filho H.H. 2007. Detection of methicillin resistance in Staphylococcus aureus isolated from pediatric patients: is the cefoxitin disk diffusion test accurate enough? Braz. J. Infect. Dis. 11(4):415-417. <http://dx.doi.org/10.1590/S1413-86702007000400009> <PMid:17873996>

Petersen A., Stegger M., Heltberg O., Christensen J., Zeuthen A., Knudsen L.K., Urth T., Sorum M., Schouls L., Larsen J., Skov R. \& Larsen A.R. 2013. Epidemiology of methicillin- resistant Staphylococcus aureus carrying the novel mecC gene in Denmark corroborates a zoonotic reservoir with transmission to humans. Clin. Microbiol. Infect. 19(1):E16-E22. <http:// dx.doi.org/10.1111/1469-0691.12036><PMid:23078039>

Quinn P.J., Markey B.K., Leonard F.C., Donnelly W.J., Fanning S. \& Maguire D. 2011. Veterinary Microbiology and Microbial Disease. John Wiley and Sons, New Jersey. 928p.

Sader H.S., Flamm R.K., Streit J.M., Farrell D.J. \& Jones R.N. 2015. Ceftaroline activity against bacterial pathogens frequently isolated in U.S. medical centers: results from five years of the AWARE surveillance program. Antimicrob. Agents Chemother. 59(4):2458-2461. <http://dx.doi. org/10.1128/AAC.04614-14><PMid:25645844>

Sader H.S., Farrell D.J., Flamm R.K., Streit J.M., Mendes R.E. \& Jones R.N. 2016. Antimicrobial activity of ceftaroline and comparator agents when tested against numerous species of coagulase-negative Staphylococcus causing infection in US hospitals. Diagn. Microbiol. Infect. Dis. 85(1):80-84. <http:// dx.doi.org/10.1016/j.diagmicrobio.2016.01.010><PMid:26971182>

Sasaki T., Tsubakishita S., Tanaka Y., Sakusabe A., Ohtsuka M., Hirotaki S., Kawakami T., Fukata T. \& Hiramatsu K. 2010. Multiplex-PCR method for species identification of coagulase-positive staphylococci. J. Clin. Microbiol. 48(3):765-769. <http://dx.doi.org/10.1128/JCM.01232-09> $<$ PMid:20053855>

Velasco D., del Mar Tomas M., Cartelle M., Beceiro A., Perez A., Molina F., Moure R., Villanueva R. \& Bou G. 2005. Evaluation of different methods for detecting methicillin (oxacillin) resistance in Staphylococcus aureus. J. Antimicrob. Chemother. 55(3):379-382. <http://dx.doi.org/10.1093/ jac/dki017><PMid:15722394>

Weese J.S. \& Van Duijkeren E. 2010. Methicillin-resistant Staphylococcus aureus and Staphylococcus pseudintermedius in veterinary medicine. Vet. Microbiol. 140(3/4):418-429. <http://dx.doi.org/10.1016/j.vetmic.2009.01.039> <PMid:19246166>

Wu S., Piscitelli C., Lencastre H. \& Tomasz A. 1996. Tracking the evolutionary origin of the methicillin resistance gene: cloning and sequencing of a homologue of mecA from a methicillin susceptible strain of Staphylococcus sciuri. Microb. Drug Resist. 2(4):435-441. <http://dx.doi.org/10.1089/ mdr.1996.2.435><PMid:9158816> 